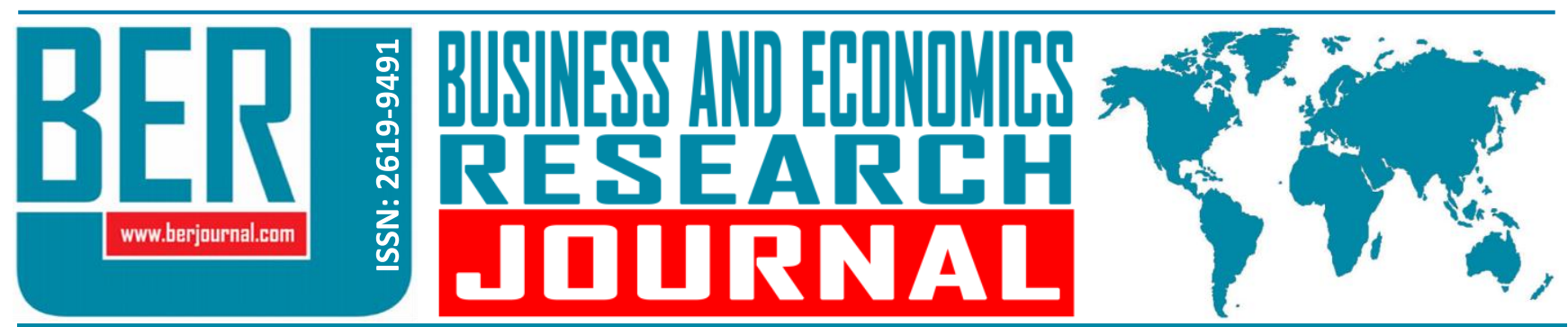

Business and Economics Research Journal Vol. 10, No. 4, 2019, pp. 991-1004 doi: 10.20409/berj.2019.215

\section{Güdülenmiş Tüketici Yenilikçiliğinin Değiştirme Maliyeti ve Algılanan Değer Üzerindeki Etkisine Yönelik Bir Model Önerisi: Akıllı Telefon Pazarı Örneği}

\author{
Emel Faiz ${ }^{\mathrm{a}}$, Gamze Uludag ${ }^{\mathrm{b}}$
}

Öz: Bu araştırmanın temel amacı, akıllı telefon pazarında güdülenmiş tüketici yenilikçiliğinin değiştirme maliyeti ve algılanan değer üzerindeki etkisini tespit ederek yeni bir model önerisi sunmaktır. Araştırma evrenini akıllı telefon satın alan ve/veya kullanan 17 yaş ve üzeri tüketici grubu oluşturmaktadır. Araştırmada kolayda örnekleme yöntemi kullanılarak 385 akılı telefon kullanıcısından online anket tekniğiyle veriler toplanmıştır. Toplanan veriler yapısal eşitlik modellemesiyle analiz edilmiş ve oluşturulan modelin yapı geçerliliği test edilmiştir. Araştırma sonucunda; sosyal, hedonik ve bilişsel yenilikçiliğin değiştirme maliyeti üzerinde etkili olduğu ancak fonksiyonel yenilikçilik boyutunun değiştirme maliyeti üzerinde etkili olmadığı sonucuna ulaşılmıştır. Hedonik yenilikçilik algılanan değer üzerinde etkiliyken diğer boyutların (sosyal, fonksiyonel ve bilişsel) algılanan değer üzerinde etkili olmadığı sonucuna ulaşılmıştır. Değiştirme maliyetinin ise algılanan değer üzerinde etkili olduğu sonucuna ulaşılmıştır.

\section{A Model Proposal for the Effect of Motivated Consumer Innovation on the Switching Cost and Perceived Value: The Case of Smart Phone Market}

\begin{abstract}
The main objective of this research is to present a new model proposal by identifying the impact of switching cost and perceived value of motivated consumer innovation driven in the smartphone market. The research population consists of 17 years old and over consumer group who buy and use smart phones. In the research, the data obtained through online questionnaire from 385 smartphone users with using convenience sampling method were collected. The collected data were analyzed under AMOS 22 program and the construct validity of the model was tested. As a result of the research; it was concluded that social, hedonic and cognitive innovation had an impact on the switching cost but that the functional innovation dimension did not have an impact on the switching cost. While hedonic innovation was effective on perceived value, it was concluded that other dimensions (social, functional and cognitive) did not affect perceived value. It was concluded that the switching cost was effective on the perceived value.
\end{abstract}

\author{
Anahtar Sözcükler: \\ Güdülenmiş Tüketici \\ Yenilikçiliği, Değiştirme \\ Maliyeti, Algılanan Değer, \\ Akıllı Telefon Kullanıcısı \\ JEL: M10, M31, C12, C42

$\begin{array}{ll}\text { Geliş } & : 05 \text { Mart } 2019 \\ \text { Düzeltme } & : \text { 30 Nisan } 2019 \\ \text { Kabul } & : \text { 20 Haziran } 2019 \\ \text { Tür } & : \text { Araştırma }\end{array}$

Keywords: Motivated Consumer Innovation, Switching Cost, Perceived Value, Smart Phone Users

JEL: M10, M31, C12, C42

$\begin{array}{ll}\text { Received } & : 05 \text { March } 2019 \\ \text { Revised } & : 30 \text { April } 2019 \\ \text { Accepted } & : \text { 20 June } 2019 \\ \text { Type } & \text { : Research }\end{array}$

a Asst. Prof., PhD., Duzce University, Faculty of Business Administration, Department of International Trade, Duzce, Turkiye, emelgokmenoglu@duzce.edu.tr (ORCID ID: 0000-0002-1911-7706)

b PhD. Candidate, Duzce University, Graduate School of Social Sciences, Department of Business Administration, Duzce, Turkiye, gamzeuludag1993@hotmail.com (ORCID ID: 0000-0002-6504-1079) 


\section{Giriş}

Sürekli değişen teknoloji ve çevre koşullarında bireylerin istek ve beklentileri de değişerek tatmin edilmesi güç bir hale gelmiştir. İşletmeler bulundukları sektörde rekabet üstünlüğü elde edebilmek için tatmin edilmesi zor olan müşteri ihtiyaçlarını karşılayacak "yenilikler" üreterek onlarda istek uyandırmaya çalışmaktadır. Ancak işletmelerin sundukları bu yenilikler her zaman pazarda başarılı olamamaktadır. Bir yeniliğin tüketiciler tarafından benimsenmesi ve yayılmasının sağlanması pazardaki başarının anahtarıdır. Bu nedenle yeniliklerin benimsenmesini ve yaygınlaşmasını sağlayan tüketici yenilikçiliği önemli bir kavram haline dönüşmüştür. Ancak pazara sunulan yenliklerin benimsenmesi bireyden bireye farklılık göstermektedir. Bazı bireyler yeniliği, çevresi tarafından kabul ve saygınlık görmek için, bazı bireyler yeniliği hayatlarını kolaylaştırıcı çözümler sunduğu için, bazı bireyler ise kendilerinin mutlu ve iyi hissetmek için satın almayı istemektedir. Bahsi geçen tüm tüketici yenilikçiliği türlerinin en çok gözlemlendiği sektörlerin başında akılı telefon sektörü bulunmaktadır. Akıllı telefon sektörü sadece tüketici için değil işletmelerin de sıklıkla yeniliğe başvurdukları bir sektör olarak karşımıza çıkmaktadır. İşletmelerin sürekli olarak yenilik yaptığı akıllı telefon sektörü, tüketicilerin hayatını kolaylaştırdığından dolayı vazgeçemeyeceği bir unsur haline dönüşmüş ve tüketicilerin neredeyse her iki yılda bir akıllı telefonlarını değiştirdiği gözlemlenmiştir (Karaaslan ve Budak, 2012: 4567). Akıllı telefonlarını sıklıkla değiştirip güncel modeli satın alan tüketici için o telefondan elde ettiği faydanın ve karşııı̆ında katlandığı bedelin kendisi açısından bir değeri de bulunmaktadır. Tüketiciler için bu algılanan değer olarak ifade edilmekte ve kişiden kişiye göre değişiklik göstermektedir. Tüketici elde ettiği fayda ve yaptığı fedakârlıklar arasında bir denge kurarak yeni bir akıllı telefon satın alma kararı vermektedir. Bir tüketici için her yeni akıllı telefon satın alma işlemi, sadece yeni modeli benimseyip satın alması anlamına gelmemekte bazen yeni modelle beraber işletim sistemini ve kullanıcı ara yüzünü de değiştirmesi anlamına gelmektedir. Değişen işletim sistemi ve kullanıcı ara yüzü, yeni yazılım güncellemesi tüketiciler için maddi ve manevi bir maliyet anlamı da taşımaktadır. İşte bu noktada değiştirme maliyeti kavramı ortaya çıkmaktadır. Bu kapsamda akıllı telefonlarla ilgili bir yenilik pazara sürülürken bu yeniliğin tüketiciler tarafından kabul edilmesi ve yaygınlaşması, pazara sürülen farklı marka ya da modele geçiş yapabilmek için katlanılan maliyetler ve bu yeniliklerin tüketicilere sağladığı değerin araştırılması ve ilişkilerin belirlenmesi bu alanda çalışan araştırmacılara ve uygulayıcılara yol gösterici nitelik taşımaktadır.

Akıllı telefonların varlığının hem tüketiciler hem de pazara sunan markalar için önemi arttıkça alan yazında akademisyenler tarafından da araştırılmaya değer verilen bir alan haline gelmiştir. Araştırmacıların çoğu akıllı telefon sektörünü ve akıllı telefon sektöründeki tüketicileri dikkate alan çalışmalar gerçekleştirmektedir. Bu çalışmalar incelendiğinde algılanan değer, değiştirme maliyeti ve tüketici yenilikçiliği değişkenlerini ayrı ayrı ele alan araştırmalara rastlamak mümkündür (Lee, Lee ve Feick, 2001; Nakamura, 2010; Yoo, Yoon ve Choi, 2010; Kim, Seoh, Lee ve Lee, 2010; Chung ve Chun, 2011; Kirsi, 2011; Ling ve Yuan, 2012; Bakon ve Hassan, 2013; Park ve Koo, 2016; Tussyadiah, 2016). Ancak taranılan veritabanları kapsamında tüketici yenilikçiliğinin tüketicinin algıladığı değer ve bir markadan diğer markaya geçişteki algıladığı değiştirme maliyeti üzerindeki etkisini ölçen ve model haline getiren bir çalışmaya rastlanılmamıştır. Üç değişkeni birlikte ele alıp bir model önerisi sunması nedeniyle bu çalışmanın literatüre katkısının olacağı düşünülmekte ve keşifsel bir araştırma olması hasebiyle de gelecekte bu alanda yapılacak araştırmalara öncülük edeceği varsayılmaktadır.

\section{Literatür}

\subsection{Güdülenmiş Tüketici Yenilikçiliği}

Midgley ve Dowling (1978: 236) yenilikçiliği, bir bireyin yeni fikirlere açık olma derecesi ve diğer kişilerin deneyimlerine bakılmaksızın bunları benimsemeye karar vermesi olarak tanımlamıştır. Tüketici yenilikçiliği, bireyin bir yeniliği ait olduğu sosyal sistemde yer alan diğer bireylerden nispeten daha erken benimsemesidir (Rogers, 2002: 990). Midgley (1977), sosyal gruptaki diğer üyelerin denetimlerinden bağımsız olarak bireyin yenilik ile ilgili karar verme derecesi, Steenkamp vd. (1999) ise tüketici yenilikçiliğini önceki tercihlerin ve tüketim şekillerinin tamamen aynı kalması yerine farklı yeni ürün veya markaların satın alınması eğilimi olarak ifade etmektedir. 
Tüketici yenilikçiliği kavramı hem pazarlama teorisi hem de pazarlama uygulamaları için önemlidir. Çünkü işletmeler büyüme ve devamlılığını sağlayabilmek için pazara sundukları yeni ürünlerinin tanıtımı ve tüketiciler tarafından benimsemesi açısından önemli bir fonksiyondur (Steenkamp vd., 1999: 55; Nasution ve Garnida, 2010: 1). Pazara sürülen bir ürünün benimsenme derecesi tüketici yenilikçiliği kavramı ile ölçülmektedir. Çünkü tüketicilerin, yeni mal ve hizmetleri benimsemeye istekli olduğunu anlamanın bir yolu olduğu düşünülmektedir. Bu nedenle tüketici yenilikçiliği, yeni ürün yayılımı ve benimsenmesinde önemli bir faktör olarak görülmektedir (Saeed, Zameer, Awan ve Ullah, 2014: 342).

Tüketici yenilikçiliği kavramı üzerine literatürde iki temel yaklaşım öne sürülmektedir. İlki tüketici yenilikçiliğinin bir kişilik özelliği olduğu üzerinedir. Bu yaklaşımda kişisel bir özellik olarak aktarılan tüketici yenilikçiliği bireylerin yenilik yapabilme yetisini ve derecesini ifade etmektedir (Midgley ve Dowling, 1978: 276). Tüketici yenilikçiliği az ya da çok her bireyde var olan kişisel bir özelliktir (Aydın, 2009: 190). íkinci yaklaşımda ise, ürün temelli yenilikçilik olarak değerlendirilmekte ve tüketicilerin her ürün için yenilikçiliklerinin değişebileceğini vurgulamaktadır (Bülbül ve Özoğlu, 2014: 44).

Tüketici yenilikçiliği kavramı birçok araştırmacı tarafından farklı boyutlarla ele alınarak ölçülmeye çalışılmıştır. Midgley ve Dowling'in (1978: 239) Kişisel Yenilikçilik Ölçeği, Raju'nun (1980) Yenilikçilik Ölçeği, tüketici eğilimlerini "keşifsel davranışa" yönelik ölçmek için tasarlanmıştır. Venkatraman ve Price'ın (1990) Bilişel ve Duygusal Yenilikçilik Ölçeği, Goldsmith ve Hofacker'ın (1991) ilgi Alanına Özgü Yenilikçilik Ölçeği, Roehrich'in (1994) Hazcı ve Sosyal Yenilikçilik Ölçeği, Le Louarn (1997), yenilikçiliğe yatkınlığı ölçen Yeniliğin Cazibesi, Yenilikçi Kararda Özerklik ve Yeniliğin Denenmesinde Risk Alma Yeteneği kapsayan ölçeği, Vandecasteele ve Geuens'un (2010) Güdülenmiş Tüketici Yenilikçiliği Ölçeği bulunmaktadır. Bartels ve Reinder (2011) ise, Kişilik Özelliği Olarak Yenilikçilik (Doğuştan Yenilikçilik), illgi Alanına Özel Yenilikçilik ve Gerçekleştirilmiş Davranış Olarak Yenilikçilik (Yenilikçi Davranış) olmak üzere tüketici yenilikçiliğini üç boyuta ayırmıştır. Görüldüğü gibi, bu konu ile ilgili olarak literatürde birçok ölçek bulunmaktadır. Ancak bu ölçekler yenilikçiliğin sadece bir ya da birkaç özelliği hakkında vurgu yapmaktadır. Yani bazı ölçeklerin sadece kişisel özelliklere dayanması ya da fazla ürün odaklı olması yönüyle eleştirilmektedir. Vandecasteele ve Geuens (2010) tartışılan bu eksiklikleri gidermek amacıyla Güdülenmiş Tüketici Yenilikçiliği ölçeğini geliştirmiştir (Kavak, Taner ve Kazancı, 2016: 95-96).

Güdülenmiş tüketici yenilikçiliği hedonik yenilikçilik, bilişsel yenilikçilik, sosyal yenilikçilik ve fonksiyonel yenilikçilik olmak üzere dört boyuttan oluşmaktadır (Vandecasteele ve Geuens, 2010: 309; Kavak vd., 2016: 97):

- Hedonik Yenilikçilik: Duyguları harekete geçirmeyi amaçlayan ürünlerin keşif edilmesi ve satın alınmasıdır. Tüketiciler yenilikleri kullanmaktan haz duymakta ve kendilerini daha mutlu hissetmektedir. Böylece tüketiciler haz duygusuyla yeni ürünlere yönelmektedir.

- Fonksiyonel Yenilikçilik: İşlevsel ve kullanışlı yeni ürünlere ilgi duyan yenilikçi tüketiciler bu grupta yer almaktadır. Tüketici söz konusu yenilikleri tüketerek zaman tasarrufu ettiğini düşünmekte ve yenilik sayesinde işlerinin daha kolay ve sorunsuz bir şekilde yürüdüğünü düşünmektedir. Bu nedenle tüketiciler yenilikleri satın alırken hedonik ve duygusal nedenlerden ziyade faydacı nedenlerinden dolayı satın almaktadırlar.

- Sosyal Yenilikçilik: Satın alınan ürünler her zaman hedonik ve fonksiyonel değerleri için alınmaz. Bazen tüketiciler başkalarını etkileyebilmek ve sosyal statülerini yükseltmek için yenilikleri satın almaktadır. Yeniliklere sahip olmanın, toplum tarafından kabul görmüş izlenimi oluşturmaktadır. Tüketici yenilikleri kullandığında kendini çevresinden farklılaştığını ve saygınlığını arttırdığını düşünmektedir. Tüketicilerin bu yenilikleri kullanması toplum içerisinde onlara prestij sağlayarak bir kimlik kazandırdığını düşündürmektedir.

- Bilişsel Yenilikçilik: Düşünmeyi gerektiren ve yeni deneyimlerden keyif alma eğilimidir (Saeed vd., 2014: 342). Tüketici zihnini çalıştırmak amacıyla yeni ürünleri deneyimleme ve satın alma arzusunda bulunur. Tüketici problemlerini çözmeye odaklı olup, zihnini çalıştıran ve bilgileri artıran mantıksal olarak kabul ettiği yenilikleri satın alma eğilimi göstermektedir. 


\subsection{Değiştirme Maliyeti}

Birçok sektörde, müşteriler bir işletme ya da sunduğu üründen rakip işletme ya da ürüne geçiş yapmak istediğinde önemli maliyetlerle karşı karşıya kalmaktadır (Shy, 2002: 71). Bu maliyetler, değiştirme maliyeti olarak adlandırılmaktadır ve değiştirme maliyeti, bir müşterinin bir işletmeyi değiştirmek istemesiyle ne gibi maliyetlere katlanacağını belirlenmesini sağlamaktadır (Şahin, 2017: 23-24).

Heide ve Weiss (1995: 33), müşterinin bir tedarikçiden diğerine geçerken katlandığı değişme masrafı olarak ifade etmiştir. Caruana (2003: 257) değiştirme maliyetini, bir işletmeden veya ürününden diğer rakip işletmeye veya ürününe geçmek için müşterinin katlandığı "tek seferlik maliyet", Oyeniyi ve Abiodun (2010: 112) ise değiştirme maliyetini, müşteriler tarafından mevcut işletmesi ile arasındaki ilişkisini sona erdirmek ve farklı bir rakip işletmeyle yeni bir ilişki başlatmak için yapılan maliyetler olarak tanımlamaktadır. Değiştirme maliyeti, müşterinin mevcut işletmesine sadık kalması durumunda yaşanmayacaktır ancak diğer rakip işletmelere geçiş yapması durumunda ortaya çıkarak müşterinin maruz kaldığı maliyet olarak ifade edilmektedir (Ningsih ve Segoro, 2014: 1016).

$\mathrm{Bu}$ tanımlamalar genellikle değiştirme maliyetinin kapsamını belirlemede yetersiz kalmıştır. Bu nedenle birçok yazar değiştirme maliyetini etkileyen tüm unsurları içine alan tanımlar yapmıştır. Buradan hareketle değiştirme maliyeti Jackson (1985) tarafından, bir müşterinin devamlı alışveriş yaptığı işletmeyi değiştirmesi halinde katlandığı psikolojik, fiziksel ve ekonomik maliyetlerin bütünüdür. Değiştirme maliyeti, nesnel olarak ölçülebilen parasal maliyetlere ek olarak, müşterilerin yeni bir işletmeye geçerken zaman kaybetmesi ve psikolojik çaba sarf etmesidir (De Ruyter, Wetzels ve Bloemer, 1998: 439). Kısacası, değiştirme maliyeti hem parasal hem de parasal olmayan maliyetleri (örneğin: harcanan zaman ve psikolojik çaba) içerir (Wang, 2010: 254). Bu nedenle değiştirme maliyeti, nesnel olarak ölçülebilen parasal maliyetlerin yanında tüketicilerin psikolojik çabasına ve harcadığı zamana dayandığından kısmen tüketiciye özgüdür (Shy, 2002: 72).

Değiştirme maliyeti diğer ürünlerde olduğu gibi akıllı telefon sektöründe de piyasa rekabet gücü arasındaki ilişkide kullanılan önemli araçlardandır. Mobil telefonun değiştirme maliyeti, mobil cihazın veya telekomünikasyon servis sağlayıcısının değiştirilmesinin neden olduğu ekonomik ve psikolojik maliyetlerdir. Akıllı telefon değişikliği durumunda değiştirme maliyetleri telekomünikasyon şirketi, cihaz veya işletim sistemi platformunun değiştirilmesinden kaynaklanmaktadır. Apple ve Google gibi işletim sistem sağlayıcıların herkesin özgürce uygulama satın alıp, satabileceği ve kolayca uygulama indirebileceği sistem kurması ve akıllı telefonların bu çeşitli uygulamaların kurulumunu desteklemesiyle birlikte tüketici ihtiyaçları her alanda karşılanmaya çalışıımaktadır. Akıllı telefonun sağladığı avantajlar kadar tüketicilerin kullandıkları akıllı telefonu değiştirmesinden kaynaklanan birçok maliyette ortaya çıkmaktadır. Bu maliyetlerden ilki Apple ve Google'ın farklı işletim sistemleri kullanmasından kaynaklanmaktadır. Apple IOS ve Google Android işletim sistemini kullandıklarından indirilen uygulamalar farklı işletim sistemlerinde uyumlu değildir. Her iki işletim sisteminin kendine ait seçenekleri bulunmaktadır ve bu yüzden birbirini desteklememektedir. Bu durum, tüketicilerin farklı bir işletim sistemine sahip akıllı telefona geçtikten sonra satın aldığı uygulamaları kullanamayacağı anlamına gelmektedir. Ayrıca farkı bir işletim sistemine geçmek tüketicilere öğrenme maliyeti olarak yansımaktadır. Açıkça, mevcut bir akıllı telefona alışkın olan bir tüketici, farklı işletim sistemlerine veya kullanıcı arayüzlerine sahip diğer akıllı telefonları öğrenebilmesi zaman ve çaba gerektirmekte bu da tüketiciye öğrenme maliyeti olarak yansımaktadır. Eklenen faktörlerden biri de yeni bir akılı telefon satın alırken daha önce kullanılmış bir akıllı telefonla uyumlu olmayan parçalar ek maliyetlere neden olmaktadır. Örneğin bir akıllı telefon için kullanılan güç kabloları ve diğer aksesuarlar yeni bir akıllı telefonla uyumlu olmamaktadır (Park ve Koo, 2016). Bu değiştirme maliyetlerine psikolojik açıdan bakacak olursak, akıllı telefonunu değiştiren bir tüketicinin yeni markaya alışma ve benimseme dönemi bir maliyet unsuru olarak tüketiciye yansıyacaktır.

\subsection{Algılanan Değer}

Tek bir ürün kategorisinde bile değer kavramı tüketiciden tüketiciye farklılaşmaktadır. Bunun en önemli nedeni tüketicinin kendine özgü ve kişisel bir nitelikte olmasından kaynaklanmaktadır. Bu kapsamda 
değerlendirilen keşfedici çalışmaların sonuçlarına göre değer; (1) değer, düşük fiyattır, (2) değer, bir tüketicinin üründen beklediği ve istediği her şey olarak tanımlanmaktadır, (3) değer, bir tüketicinin ödediği fiyat karşılığında elde ettiği kalitedir, (4) değer, tüketicinin verdiği şeyleri geri almasıdır (Zeithaml, 1988: 13) şeklinde dört grup altında toplanmaktadır.

Dodds, Monroe ve Grewal (1991: 308) algılanan değeri, üründe aldıkları kalite veya faydalar ile fiyatı öderken katlandığı fedakarlıklar arasındaki denge olarak ifade etmektedir. Gale ve Wood (1994: 14) ise algılanan değerini, kalite ve fiyatın basit bit oranı olarak kavramsallaştırmaktadır. Bir başka tanıma göre algılanan değer, müşterileri ürüne bağlayan ve bu ürüne verdiği değer sonucunda elde edeceği faydaların toplamı olarak ifade etmiştir (Huang ve Zhang, 2008: 102). Algılanan değer kavramı, doğası gereği algısaldır ve parasal olarak ifade edilmektedir. Mevcut alternatif bir işletmenin ürünleri ve fiyatları göz önünde bulundurularak, bir ürün teklifi için ödenen fiyat karşılığında müşteri tarafından alınan ekonomik, teknik, hizmet ve sosyal faydaların toplamı olarak kavramsallaştırılmaktadır (Anderson, Jain ve Chintagunta, 1992: 5).

Butz ve Goodstein (1996: 63) ise, müşteri ile üretici arasında gerçekleşen ve müşterinin, üreticinin ürettiği mal veya hizmeti kullandıktan sonra oluşturduğu duygusal bağ olarak tanımlamaktadır. Tüketiciler, üründen aldıkları (yani faydaları) ve vazgeçmek zorunda kaldıkları şeylere (yani fedakârlıklara) dair algılarını bilişsel olarak bütünleştirmesidir. Yani algılanan değer, faydalar ve fedakârlıklar arasında bir denge gerektirmektedir. Sun (2009: 281) ise bilişsel değerlendirme yerine algılanan değeri, müşterilerin satın almalarından ve tüketilmesinden sonra oluşan öznel değerlendirmesi olarak tanımlamıştır.

Tüketicilerin bir akıllı telefondan elde ettiği değer fonksiyonel, sosyal, bilişsel ve duygusal olmak üzere ayrılmaktadır. Bir akıllı telefon için güvenilirlik, dayanıklılık ve fiyat gibi unsurlar fonksiyonel değeri türetmektedir. Uygun fiyat akıllı telefon kullanıcılarının tüketim kararında fonksiyonel değeri ortaya çıkaran en etkili faktörlerden biri olarak kabul edilir. Bunun yanında kullandıkları akıllı telefonun kalite ölçüsü olarak pil örünün uzun olması, günümüz koşullarında sosyal medyanın aktif kullanılması ile paralel olarak kameraların yüksek çözünürlükte olması ve kullanılan telefonların dayanıklı olması tüketiciler için sağlanan diğer değer ifade eden özellikler arasındadır (Bakon ve Hassan, 2013). Ancak tüketiciye her sağlanan kalite göstergesi unsurlarda akıllı telefona ödenen fiyat artmaktadır. Akıllı telefona tüketicilerin istekleri üzerine eklenen her özellik fiyat artışı yaratmaktadır. Bu bakımdan algılanan değer, ödeme niyetinin ana belirleyicisidir (Hsiao, 2013: 217).

Tüketiciler akıllı telefon satın alırken fiyat ve kalite dışında onlara katacağı sosyal değer, bilişsel değer ve duygusal değer içinde satın almaktadır. Sosyal değer yani akılı telefonun sağlayacağı sosyal imaj tüketiciler için önemli bir değer unsurudur. Yani akıllı telefonunun satın alınmasının en son trendlerin ön planına çıkarmasıyla yakından ilişkilidir. Birçok müşteri, kendi imajını geliştirmek için akıllı telefon satın almaktadır. Bir diğer unsur duygusal değer, akıllı telefonun kullanım kolaylığı, tasarımı ve kullanışlılığıdır. Eğer bir akıllı telefondan elde edilen deneyim olumlu ve zevkli ise tüketiciler bu akıllı telefonla duygusal bir bağ kurmaktadır. Son değer çeşidi ise, merak ya da yeniliğe dayalı tüketicilerin satın alma kararı vermesini sağlayan bilişsel değerdir. Tüketiciler bazı durumlarda mevcut ürünlerden sıkılmış hissederler ve sunulan akıllı telefon yeniliği onları etkileyerek satın almalarını sağlamaktadır (Bakon ve Hassan, 2013).

\section{Yöntem}

\subsection{Araştırma Modeli ve Hipotezleri}

Araştırmanın amacı ve kapsamı gereği nicel araştırma desen türlerinden nedensel tarama araştırması kullanımıştır. Literatürde taranılan veri tabanları kapsamında, modele konu olan üç değişken arasındaki ilişkiye ait bir model önerisinin bulunmaması sebebiyle akıllı telefon kullanıcıları ve bu sektörde yer alan işletmeler düşünülerek bir model geliştirilmeye ve test edilmesine yönelik çalışma tasarlanmıştır. Bu kapsamda, araştırma konusu olan güdülenmiş tüketici yenilikçiliği boyutlarının (sosyal, fonksiyonel, hedonik, bilişsel) değiştirme maliyeti ve algılanan değer üzerindeki etkisini belirlemek için çalışmanın temelini oluşturan araştırma modeli Şekil 1'de gösterilmektedir. 


\section{Şekil 1. Araştırma Modeli}

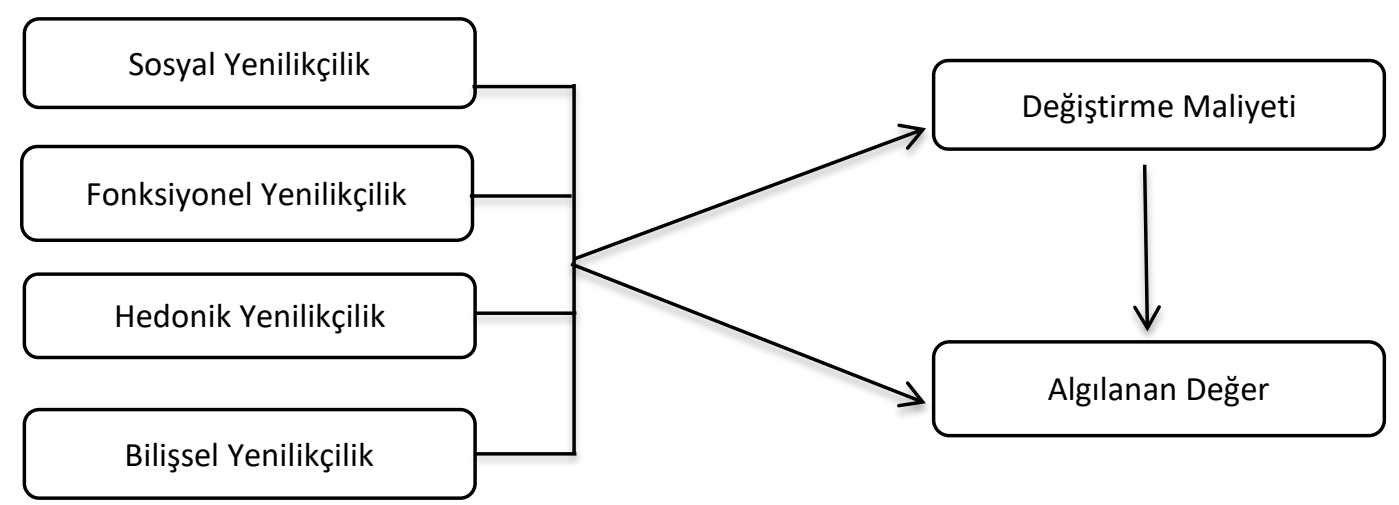

Güdülenmiş tüketici yenilikçiliğinin (sosyal, hedonik, fonksiyonel ve bilişsel) değiştirme maliyeti ve algılanan değer üzerindeki etkisi dikkate alarak model çizilmiş ve hipotezler oluşturulmuştur. Literatürde araştırma modeli kapsamında yer alan değişkenler arasındaki ilişkilere ilişkin daha önceden farklı araştırmalarda elde edilmiş bulgular mevcuttur. Tüketici yenilikçiliği ile algılanan değer arasındaki ilişkiyi inceleyen Hong, Lin ve Hsieh (2017)'nin akıllı saat kullanımına yönelik gerçekleştirdikleri araştırmalarında tüketici yenilikçiliğinin algılanan değerin boyutları ile pozitif ilişkili olduğu görülmüştür. Samudro, Sumarwan, Yusuf ve Simanjuntak (2018), müşteri sadakatinin öncüllerini araştırdıkları çalışmalarında değiştirme maliyeti ve algılanan değer arasındaki ilişkiye de odaklanmakta ve yüksek algılanan değerin yüksek değiştirme maliyetine kıyasla belli bir marka ile ilişkide kalmanın temelini oluşturduğunu ifade etmektedir. Değiştirme maliyeti ile algılanan değer arasındaki ilişki müşterinin marka değiştirme kararında etkili olmaktadır. Yang ve Peterson (2004)'e göre, müşterilerin markaya dair algıladığı değerin belirli bir ortalamada olup olmaması marka değiştirme kararını ve değiştirmenin müşteride yaratacağı maliyeti etkilemektedir.

$\mathbf{H}_{1}$ : Sosyal yenilikçiliğin değiştirme maliyeti üzerinde etkisi vardır.

$\mathbf{H}_{\mathbf{2}}$ : Fonksiyonel yenilikçiliğin değiştirme maliyeti üzerinde etkisi vardır.

$\mathbf{H}_{3}$ : Hedonik yenilikçiliğin değiştirme maliyeti üzerinde etkisi vardır.

$\mathrm{H}_{4}$ : Bilişsel yenilikçiliğin değiştirme maliyeti üzerinde etkisi vardır.

$\mathbf{H}_{5}$ : Sosyal yenilikçiliğin algılanan değer üzerinde etkisi vardır.

$\mathbf{H}_{6}$ : Fonksiyonel yenilikçiliğin algılanan değer üzerinde etkisi vardır.

$\mathbf{H}_{7}$ : Hedonik yenilikçiliğin algılanan değer üzerinde etkisi vardır.

$\mathbf{H}_{\mathbf{8}}$ : Bilişsel yenilikçiliğin algılanan değer üzerinde etkisi vardır.

$\mathbf{H}_{9}$ : Değiştirme maliyetinin algılanan değer üzerinde etkisi vardır.

\subsection{Araştırmanın Evreni ve Örneklemi}

Global Mobile Market (2018) raporuna göre Türkiye'de 44.771 .000 akıllı telefon kullanıcısı bulunmaktadır. Araştırma kapsamında herhangi bir akıllı telefon markasını satın alan veya kullanan 17 yaş ve üzeri tüketiciler araştırmanın evrenini oluşturmaktadır. Türkiye genelinde 17 yaş ve üzeri akıllı telefon kullanııılarına ulaşmanın mümkün olmaması durumdan ötürü örneklem seçme yöntemine gidilmiştir. Türkiye genelinde 17 yaş ve üzeri akıllı telefon kullanan tüketici sayısına özgü istatiksel olarak bir bilgiye ulaşılmadığı için Sekaran'ın Tablosundan yararlanılmıştır. Bu tablodan elde edilen veriye göre 100.000 üzeri evren büyüklüğünde evreni temsil edebilecek örneklem sayısı 384 ve üzeri olarak belirlenmiştir (Sekaran, 2000). Bu kapsamda araştırmada evreni temsil edebilecek 385 akıllı telefon kullanıcısına kolayda örnekleme yöntemi kullanılarak ulaşıımıştır. 


\subsection{Veri Toplama Araçları ve Veri Toplama Süreci}

Akıllı telefon kullanıcılarının sosyal medya araçlarını aktif kullanmalarından ötürü anket online şekilde tasarlanmıştır (Malhotra, 2010: 219). Araştırma kapsamında verileri elde edebilmek için oluşturulan online anket formu iki bölümden oluşmaktadır. Anketin ilk bölümünde, 5 ifadeden oluşan değiştirme maliyetine ait ifadeler Gefen (2002: 48)'nın çalışmasından, 2 ifadeden oluşan algılanan değer ölçeğine ait ifadeler Fornell, Johnson, Anderson, Cha ve Bryant (1996)'nin çalışmasından, 20 ifade ve 4 boyut (sosyal, fonksiyonel, hedonik ve bilişsel) altında toplanan güdülenmiş tüketici yenilikçiliği ölçeği ise Vandecasteele ve Geuens (2010)'in çalışmasından akıllı telefon kullanıılarına yönelik olarak uyarlanmıştır. Araştırmaya katılan tüketicilerin sosyo-demografik özelliklerini ifade eden 1 ve kullandıkları akıllı telefon markasına ilişkin düşüncelerini ifade eden 3 ifade olmak üzere toplam 4 ifadeye yer verilmiştir. Anketi oluşturan ifadeler 5'li Likert tipi ölçek kullanılarak hazırlanmıştır.

\subsection{Verilerin Analizi}

Akıllı telefon kullanıcılarının sosyo-demografik özelliklerini incelemek için SPSS 18 istatistik paket programından yararlanarak betimsel istatistiklerden frekans analizi kullanılmıştır. Araştırma sürecinde verilerin analizi için AMOS 22 programı kullanılmıştır. Araştırma modelini oluşturan değişkenlerin birlikte ele alındığı ölçme modelini test etmek ve yapısal geçerliliğini sağlayabilmek amacıyla doğrulayıcı faktör analizi (DFA) yapılmıştır. Sonraki aşamada DFA ile test edilen ölçme modelinin güvenilirlik ve geçerlilik testleri yapılarak, araştırma modeli kapsamında sunulan doğrudan etkiler path (yol) analizi ile test edilmiştir.

\section{Bulgular ve Yorum}

\subsection{Katılımcıların Demografik Özellikleri}

Araştırma sürecine dâhil olan katılımcıların \%68,3'ünü kadın, \%31,7'sini erkek katılımcılar oluşturmaktadır. Yaş kriterleri değerlendirildiğinde katılımcıların \%46'sının 24-30 yaş aralığını temsil ettiği, bunu takiben \%28,6'sının 17-23, \%13,8'inin 31-37, \%6'sının 38-44, \%4,9' unun 45-51 ve geriye kalan \%0,8'inin 52-58 yaş aralığını temsil ettiği görülmektedir. Aylık toplam gelir düzeyi açısından katılımcıların \%41'inin 1.601- 3.200 TL aralığında, \%38,2'sinin $1.600 \mathrm{TL}$ ve altında, \%11,9'unun 3.201-4.800 TL aralığında, \%4,9'unun 4.801-6.400 TL aralığında, geri kalan \%3,9'luk kısmının da 6.401- 8.000 TL aralığında aylık toplam gelire sahip olduğu görülmektedir.

\subsection{Doğrulayıcı Faktör Analizi}

Araştırma kapsamında ele alınan ölçüm modelini oluşturan 6 örtük değişken ile 27 gözlenen değişkenden oluşan ölçeğin yapı geçerliliğini test etmek için AMOS 22 programı kullanılmıştır. Bu kapsamda değiştirme maliyeti ve algılanan değer değişkenleri için tek faktörlü, güdülenmiş tüketici yenilikçiliği için çift faktörlü doğrulayıcı faktör analizi yapılmıştır. Çift faktörlü doğrulayııı faktör analizi sonucunda güdülenmiş tüketici yenilikçiliği ölçeğinin aslında olduğu gibi 4 boyut altında toplanmıştır. Bu boyutlar sosyal yenilikçilik, fonksiyonel yenilikçilik, hedonik yenilikçilik ve bilişsel yenilikçiliktir. Analiz sonucunda düşük standardize edilmiş parametre değerleri gösteren ve yüksek düzeyde hata değerleri veren güdülenmiş tüketici yenilikçiliğinin boyutu olan fonksiyonel yenilikçiliğe ait FY5 ve değiştirme maliyetine ait DM1 ifadesi çıkarılmıştır (Hau ve Thuy, 2012). İstenilen uyum değerlerine ulaşabilmek için sosyal yenilikçilik ölçeğinin 4 ve 5 numaralı ifadeleri, hedonik yenilikçiliğin 1 ve 2 numaralı ifadeleri ve değiştirme maliyetinin 2 ve 3 numaralı ifadelerinin hata terimleri arasında kovaryans bağıntısı yapılmıştır. Yapılan modifikasyon sonucu ölçüm modellerinin uyum değerleri istenen sınırlarda gözlemlendiğinden değiştirme maliyeti ve algılanan değer ölçeklerinin tek faktörlü yapısı ve güdülenmiş tüketici yenilikçiliği ölçeğinin çift faktörlü yapısı doğrulanmıştır. 

Telefon Pazarı Örneği

Tablo 1. Doğrulayıcı Faktör Analizi

\begin{tabular}{|c|c|c|c|c|c|c|c|}
\hline Örtük Değişken & $\begin{array}{l}\text { Gözlenen } \\
\text { Değişken }\end{array}$ & $\begin{array}{c}\text { Standardize Edilmiş } \\
\text { Parametre Değeri }\end{array}$ & $\begin{array}{l}\text { Standart } \\
\text { Hata }\end{array}$ & t-değeri & $\mathbf{P}$ & CR & AVE \\
\hline \multirow{5}{*}{ Sosyal Yenilikçilik } & SY1 & 0,681 & & & & \multirow{5}{*}{0,842} & \multirow{5}{*}{0,519011} \\
\hline & SY2 & 0,825 & 0,092 & 13,704 & $* * *$ & & \\
\hline & SY3 & 0,805 & 0,090 & 13,486 & $* * *$ & & \\
\hline & SY4 & 0,634 & 0,078 & 10,990 & $* * *$ & & \\
\hline & SY5 & 0,633 & 0,088 & 10,962 & $* * *$ & & \\
\hline \multirow{5}{*}{$\begin{array}{l}\text { Fonksiyonel } \\
\text { Yenilikçilik }\end{array}$} & FY1 & 0,583 & & & & \multirow{5}{*}{0,830} & \multirow{5}{*}{0,560023} \\
\hline & FY2 & 0,793 & 0,117 & 10,691 & $* * *$ & & \\
\hline & FY3 & 0,806 & 0,106 & 11,498 & $* * *$ & & \\
\hline & FY4 & 0,772 & 0,114 & 10,773 & $* * *$ & & \\
\hline & FY5 & - & - & - & - & & \\
\hline \multirow{5}{*}{$\begin{array}{l}\text { Hedonik } \\
\text { Yenilikçilik }\end{array}$} & HY1 & 0,815 & & & & \multirow{5}{*}{0,907} & \multirow{5}{*}{0,662638} \\
\hline & $\mathrm{HY} 2$ & 0,850 & 0,041 & 24,853 & $* * *$ & & \\
\hline & HY3 & 0,723 & 0,059 & 15,371 & $* * *$ & & \\
\hline & HY4 & 0,859 & 0,051 & 19,243 & $* * *$ & & \\
\hline & HY5 & 0,816 & 0,055 & 17,993 & $* * *$ & & \\
\hline \multirow{5}{*}{ Bilişsel Yenilikçilik } & BY1 & 0,683 & & & & \multirow{5}{*}{0,867} & \multirow{5}{*}{0,567731} \\
\hline & BY2 & 0,702 & 0,078 & 12,399 & $* * *$ & & \\
\hline & BY3 & 0,784 & 0,076 & 13,319 & $* * *$ & & \\
\hline & BY4 & 0,828 & 0,078 & 14,283 & $* * *$ & & \\
\hline & BY5 & 0,761 & 0,080 & 12,961 & $* * *$ & & \\
\hline \multirow{2}{*}{ Algılanan Değer } & AD1 & 0,862 & & & & \multirow{2}{*}{0,791} & \multirow{2}{*}{0,65578} \\
\hline & AD2 & 0,754 & 0,100 & 8,769 & $* * *$ & & \\
\hline \multirow{5}{*}{$\begin{array}{l}\text { Değiştirme } \\
\text { Maliyeti }\end{array}$} & DM1* & - & - & - & - & \multirow{5}{*}{0,872} & \multirow{5}{*}{0,632239} \\
\hline & $\mathrm{DM} 2$ & 0,765 & & & & & \\
\hline & DM3 & 0,931 & 0,058 & 19,036 & $* * *$ & & \\
\hline & DM4 & 0,712 & 0,070 & 12,495 & $* * *$ & & \\
\hline & DM5 & 0,755 & 0,070 & 13,156 & $* * *$ & & \\
\hline
\end{tabular}

DFA sonuçları değerlendirildiğinde, oluşturulan modeldeki değerlerin 0,01 düzeyinde anlamlı sonuçlar verdiği görülmektedir. Doğrulayıcı faktör analizi sonucunda elde edilen uyum indeksleri x2 /df= 1,969, RMSEA= 0,050, NFI= 0,908, CFI= 0,952, AGFI=0,874, GFI=0,901, CMIN=504,051

Bu sonuçlar değerlendirildiğinde, NFI, CFI, AGFI ve GFI, x2 /df , RMSEA kabul edilebilir seviye uyum indekslerine sahip olduğunu tespit edilmiştir (Schermelleh-Engel, Helfried ve Hans, 2003). Yani önerilen ölçüm modeli iyi ölçüm özellikleri göstermiştir. Bu bulgulara dayanarak, yapısal modelin kabul edilebilirliğini ifade etmek mümkündür.

Doğrulayıcı faktör analizi sonucu değerlendirildiğinde ölçeği oluşturan ifadelerin faktör yüklerinin 0,50'nin üzerinde olduğu ancak iki ifadenin FY5 ve DM1 faktör yükü 0,50'nin altında olduğundan dolayı ölçekten çıkartılmıştır. Ortalama açıklanan varyans değerinin (AVE) 0,50'ten büyük olması ve yapı güvenirliğinin $(C R)$, 70 veya üstünde olması kullanılan ölçeklerin yüksek düzeyde güvenilir olduğu göstermektedir (Fornell ve Larcker, 1981'den aktaran: Yıldız ve Koç, 2017: 96). Tablo 1 değerlendirildiğinde kullanılan ölçeklerin güvenilir olduğu görülmektedir. 
E. Faiz - G. Uludag

Tablo 2. Yapı Güvenilirliği, Ayrım Geçerliliği ve Birleşme Geçerliliği

\begin{tabular}{cccccccc}
\hline & $\begin{array}{c}\text { Yapı Güvenirliği } \\
\text { (CR) }\end{array}$ & HY & SY & BY & FY & AD & DM \\
\hline HY & $(0,907)$ & 0,662638 & & & & \\
\hline SY & $(0,842)$ & & 0,519011 & & & \\
\hline BY & $(0,867)$ & & & 0,567731 \\
\hline FY & $(0,830)$ & & & 0,560023 & \\
\hline AD & $(0,791)$ & $0,368^{* *}(0,135)$ & $0,227^{* *}(0,052)$ & $0,248^{* *}(0,061)$ & $0,261^{* *(0,068)}$ & 0,65578 \\
\hline DM & $(0,872)$ & $0,204^{* *(0,041)}$ &, $287^{* *(0,082)}$ & $0,294^{* *}(0,086)$ & $0,254^{* *(0,064)}$ & $0,214^{* *(0,046)}$ & 0,632239 \\
\hline
\end{tabular}

Yapısal modeli oluşturan değişkenlerin yapı geçerliliğinin belirlenebilmesi için birleşme ve ayrım geçerliliğinin hesaplanarak değerlendirme yapılması gerekmektedir (Peter, 1981: 136). Birleşme geçerliliğinin sağlanabilmesi için AVE değerlerinin sınır değer olan 0,50'den yüksek bir değer olması gerekmektedir (Bagozzi ve Yi, 1988; Hair, Black, Babin ve Anderson, 1998). Ayrım geçerliliğinin sağlanabilmesi için de değişkenler arasındaki korelasyonların karelerinin her bir boyut için AVE değerlerinden düşük olması gerekmektedir (Fornell ve Larcker, 1981'den aktaran: Şenbabaoğlu, 2017: 378). Bu kapsamda Tablo 2 değerlendirildiğinde yapı geçerliliği için sağlanması gereken birleşme ve ayrım geçerliliği şartları sağlanmıştır.

\subsection{Yapısal Modelin Test Edilmesi: Doğrudan ve Toplam Etkiler}

Araştırma modeli kapsamında önerilen hipotezler değişkenler arasındaki doğrudan etkileri belirlemeye yönelik oluşturulmuştur. Bu kapsamda oluşturulan değişkenler arasındaki doğrudan etkiler path analizi ile değerlendirilmiştir. Analiz sonucunda model uyum iyiliği değerlerinin kabul edilebilir sınırlar içerisinde olduğu tespit edilmiştir. Model kapsamında uyum indeksleri değerlendirildiğinde $x 2 / d f=1,977$, $\mathrm{RMSEA}=0,050, \mathrm{NFI}=0,909, \mathrm{CFI}=0,952, \mathrm{AGFI}=0,873, \mathrm{GFI}=0,901, \mathrm{CMIN}=500,238$ değerlerinin uygun aralıklarda olduğu tespit edilmiştir.

Tablo 3. Hipotezlerin Test Edilmesi

\begin{tabular}{lccc}
\hline & P & B & Sonuçlar \\
\hline SY $\longrightarrow$ DM & $\mathbf{0 , 0 0 1}$ & $\mathbf{0 , 2 1}$ & Desteklendi \\
\hline FY DM & 0,290 & 0,09 & Desteklenmedi \\
\hline HY DM & $\mathbf{0 , 0 4 0}$ & $-\mathbf{0 , 1 4}$ & Desteklendi \\
\hline BY $\longrightarrow$ DM & $\mathbf{0 , 0 0 3}$ & $\mathbf{0 , 2 0}$ & Desteklendi \\
\hline SY AD & 0,839 & $-0,02$ & Desteklenmedi \\
\hline FY $\longrightarrow$ AD & 0,564 & 0,06 & Desteklenmedi \\
\hline HY $\longrightarrow$ AD & $* * *$ & $\mathbf{0 , 3 1}$ & Desteklendi \\
\hline BY $\longrightarrow$ AD & 0,722 & 0,03 & Desteklenmedi \\
\hline DM & $\mathbf{0 , 0 3 9}$ & $\mathbf{0 , 1 5}$ & Desteklendi \\
\hline
\end{tabular}

Tüm hipotezler 0,01 anlamlıık düzeyinde test edilmiştir. Sonuçlar değerlendirildiğinde, güdülenmiş tüketici yenilikçiliği boyutlarından olan sosyal yenilikçiliğin değiştirme maliyeti üzerinde $(p=0,001, \beta=0,21)$ etkili olduğu sonucuna ulaşılmıştır. Buradan hareketle, " $\mathrm{H}_{1}$ : Sosyal yenilikçiliğin değiştirme maliyeti üzerinde etkisi vardır" hipotezi kabul edilmiştir. Fonksiyonel yenilikçiliğin değiştirme maliyeti üzerinde etkili olmadığı sonucuna ulaşılmıştır $(p=0,290, \beta=0,09)$. Buradan hareketle, " $\mathrm{H}_{2}$ : Fonksiyonel yenilikçiliğin değiştirme maliyeti üzerinde etkisi vardı" hipotezi reddedilmiştir. Hedonik yenilikçiliğin değiştirme maliyeti üzerinde negatif yönde etkili olduğu $(p=0,040, \beta=-0,14)$ sonucuna ulaşılımıştır. Buradan hareketle, " $\mathrm{H}_{3}$ : Hedonik yenilikçiliğin değiştirme maliyeti üzerinde etkisi vardır." hipotezi kabul edilmiştir. Bilişsel yenilikçiliğin değiştirme maliyeti üzerinde $(p=0,003, \beta=0,20)$ pozitif yönde bir etkisi vardır. Buradan hareketle, " $\mathrm{H}_{4}$ : Bilişsel yenilikçiliğin değiştirme maliyeti üzerinde etkisi vardır" hipotezi kabul edilmiştir. Sosyal yenilikçiliğin algılanan değer üzerinde etkili olmadığı sonucuna ulaşılımıştır $(p=0,839 \beta=-0,02)$. Buradan hareketle, " $H_{5}$ : Sosyal 
yenilikçiliğin algılanan değer üzerinde etkisi vardır" hipotezi reddedilmiştir. Fonksiyonel yenilikçiliğin algılanan değer üzerinde etkili olmadığı sonucuna ulaşılmıştır $(p=0,564 \beta=0,06)$. Buradan hareketle, " $\mathrm{H}_{6}$ : Fonksiyonel yenilikçiliğin algılanan değer üzerinde etkisi vardır" hipotezi reddedilmiştir. Hedonik yenilikçiliğin değiştirme maliyeti üzerinde pozitif yönde etkili olduğu $(p=0,000, \beta=0,31)$ sonucuna ulaşılmıştır. Buradan hareketle, " $\mathrm{H}_{7}$ : Hedonik yenilikçiliğin algılanan değer üzerinde etkisi vardır" hipotezi kabul edilmiştir. Bilişsel yenilikçiliğin algılanan değer üzerinde etkili olmadığı sonucuna ulaşılmıştır $(p=0,722 \beta=0,03)$. Buradan hareketle, " $H_{8}$ : Bilişsel yenilikçiliğin algılanan değer üzerinde etkisi vardır" hipotezi reddedilmiştir. Değiştirme maliyetinin algılanan değer üzerinde pozitif yönde etkili olduğu $(p=0,039, \beta=0,15)$ sonucuna ulaşılmıştır. Buradan hareketle, " $\mathrm{H}_{9}$ : Değiştirme maliyetinin algılanan değer üzerinde bir etkisi vardır" hipotezi kabul edilmiştir.

\section{Sonuç ve Öneriler}

Bilgi ve iletişim teknolojilerindeki hızlı ve önü alınamaz gelişmeler işletmeleri değişime ve yeniliğe zorlamaktadır. İşletmeler organizasyon yapılarını, iş yapış şekillerini ve tüketicilere sundukları mal ve hizmetleri geliştirerek rekabette üstünlük sağlamaktadır. İşletmelerin yeni ürünlerinin pazarda kabul görmesi ve yayılması için tüketicilerin rolü kritik bir faktör olarak görülmektedir. Teknolojik gelişmeler sadece işletmeleri yeniliğe sürüklememekte aynı zamanda tüketicileri de yenilikleri keşfeden ve takip eden hale getirmektedir. Yenilikçi tüketiciler, işletmelerin özellikle sahip olmak istediği bir grup olarak karşımıza çıkmaktadır. Ancak bilinmektedir ki, Rogers'ın Yeniliklerin Yayılması Eğrisine göre, yenilikçiler tüm pazarın sadece \%2,5'ini oluşturmaktadır (Rogers, 1995:165). Ayrıca, işletmelerin pazara sunduğu yeni mal ve hizmetlerin pazarda yayılım hızını etkileyen tüketici grubu yenilikçilerdir (Dobre, Dragomir ve Preda, 2009: 21). Bu sebeple, tüketici yenilikçiliğinin tespiti önem kazanmaktadır. Bilişim ve iletişim teknolojileri alanında en yenilikçi sektör akıllı telefondur (Cecere, Corrocher ve Battaglia, 2015: 1). Bu kapsamda, çalışmada, yeniliğin en hızlı ortaya çıktığı ve yayıldığı akıllı telefon sektöründe güdülenmiş tüketici yenilikçiliği ele alınmaktadır. Güdülenmiş tüketici yenilikçiliği alan yazında birçok çalışmaya konu edilmiştir (Roehrich, 2004; Hirunyawipada ve Paswan, 2006; Vandecastele ve Geuens, 2010; Eryiğit ve Kavak, 2011; Akdoğan ve Karaaslan, 2013; Özoğlu ve Bülbül, 2013; Demireli, 2014; Li, Zhang ve Wang, 2015; Kambar, 2016; Kavak vd., 2016). Araştırma, alan yazında güdülenmiş tüketici yenilikçiliğini ele alan çalışmalardan algılanan değer ve değiştirme maliyeti değişkenleriyle olan ilişkisini ortaya koyarak bir model önerisi sunma amacıyla farklılaşmaktadır.

Güdülenmiş tüketici yenilikçiliği araştırmada, sosyal yenilikçilik, hedonik yenilikçilik, fonsiyonel yenilikçilik ve bilişsel yenilikçilik olmak üzere dört boyut altında ölçülmüştür. Sosyal yenilikçilik ve bilişsel yenilikçiliğin değiştirme maliyeti üzerinde pozitif ve anlamlı, hedonik yenilikçiliğin değiştirme maliyeti üzerinde negatif ve anlamlı, yine hedonik yenilikçiliğin algılanan değer ve değiştirme maliyetinin algılanan değer üzerinde pozitif ve anlamlı etkisi test edilmiş ve ortaya konulmuştur.

Araştırmadan elde edilen bulgular değerlendirildiğinde, yeni bir ürünü ilk benimseyen ve satın alan yenilikçi tüketiciler olduğundan, yüksek bir fiyata ve ürüne ilişkin tüm maliyetlere katlanmayı kabul ettikleri düşünülmektedir. Değiştirme maliyetleri akıllı bir cep telefonu kullanıcısı için, yeni bir markaya, o markanın kullandığı işletim sistemine, ara yüzlerine alışmak ve bunun yaratmış olduğu maliyetlere katlanmaktır. Ancak yenilikçi tüketiciler her yeni akıllı telefon modelini takip ederek, ilk satın alan kişiler oldukları için değiştirme maliyetlerini yüksek algılamamakta ve önemsememektedir. Bu nedenle, güdülenmiş tüketici yenilikçiliğinin iki boyutunun (bilişsel ve sosyal yenilikçilik) değiştirme maliyeti üzerinde doğrudan pozitif etkisi bulunmaktadır. Bir markadan başka bir markaya ya da geliştirilen bir üst modele geçiş yaparken katlanılan maliyetler hedonik yenilikçiliği azaltmaktadır. Çünkü artan maliyet ne kadar fazla olursa tüketicinin ödeyeceği bu maliyetler karşısında elde edeceği haz azalacaktır. Bu nedenle hedonik yenilikçilikle değiştirme maliyeti arasında negatif yönde bir ilişki bulunmaktadır. Fonksiyonel yenilikçiliğin ise değiştirme maliyeti üzerinde etkisinin olmaması ise olası bir sonuçtur. Fonksiyonel yenilikçiler, yeniliği hayatlarını kolaylaştırması için tercih ettiklerinden dolayı değiştirme maliyeti onlar için ayrı bir zorluk olarak algılanmamaktadır. Araştırma bulguları aynı zamanda güdülenmiş yenilikçilik boyutlarından sadece hedonik yenilikçiliğin algılanan değer üzerindeki pozitif etkisini göstermektedir. Haz duygusuyla yeni ürüne yönelen hedonik yenilikçi tüketiciler 
için, merak ve yenilikten elde ettiği hazzın akıllı telefondan elde ettiği değere yansıması da araştırma sonuçlarından birisidir.

Tüketici yenilikçiliği bir yeniliğin tüketiciler tarafından benimsenmesi ve yayılmasının sağlanmaktadır. Günümüzde rakipler arttıkça işletmeler farklılaşmak adına yenilikler geliştirmektedir. Ancak önemli olan bu yeniliğin benimsenmesidir. Bu noktada araştırma kapsamında her tüketiciye ait farklı yenilikçilik özelliklerinin olduğunu ve bu yenilikçilik özelliklerine göre alışveriş yaptıkları gözlemlenmektedir. İşletmeler için önemli bir öneri olarak içinde bulunduğu pazarda hedef aldığı tüketici grubunun yenilikçilik düzeylerini analiz edilmesidir. Yapılan analiz sonucunda işletmelerin belirlenen özelliklere uygun yenilikler geliştirmeleri yeniliğin tüketiciler tarafından kabulünü hızlandırarak başarı elde etmesini sağlayacaktır. Bu alanda çalışma yapacak araştırmacılara ise, yenilikçi bir sektör olan akıllı telefon sektöründe güdülenmiş tüketici yenilikçiliğini algılanan risk, markaya duyulan güven ve marka imajı gibi değişkenlerle ilişkilendirerek yeni model önerileri geliştirmeleri önerilebilir.

\section{Kaynaklar}

Akdoğan, M. Ş., \& Karaarslan, M. H. (2013). Tüketici yenilikçiliği. Atatürk Üniversitesi iktisadi ve Idari Bilimler Dergisi, 27(2), 1-20.

Anderson, J. C., Jain, D. C., \& Chintagunta, P. K. (1992). Customer value assessment in business markets: A state-ofpractice study. Journal of Business-to-Business Marketing, 1(1), 3-29.

Aydın, S. (2009). Kişisel ve ürün temelli yenilikçilik: Cep telefonu kullanıcıları üzerine ampirik bir uygulama. Doğuş Üniversitesi Dergisi, 10(2), 188-203.

Bagozzi, R. P., \& Yi, Y. (1988). On the evaluation of structural equation models. Journal of The Academy of Marketing Science, 16(1), 74-94.

Bakon, K., \& Hassan, Z. (2013). Perceived value of smartphone and its impact on deviant behaviour: An investigation on higher education students in Malaysia. International Journal of Information System and Engineering (IJISE), 1(1), 1-17.

Bartels, J., \& Reinders, M. J. (2011). Consumer innovativeness and its correlates: A propositional inventory for future research. Journal of Business Research, 64(6), 601-609.

Butz Jr., H. E., \& Goodstein, L. D. (1996). Measuring customer value: Gaining the strategic advantage. Organizational Dynamics, 24(3), 63-77.

Bülbül, H., \& Özoğlu, B. (2014). Tüketici yenilikçiliği ve algılanan riskin satın alma davranışına etkisi. Erciyes Üniversitesi iktisadi ve Idari Bilimler Fakültesi Dergisi, 44, 43-58.

Caruana, A. (2003). The impact of switching costs on customer loyalty: A study among corporate customers of mobile telephony. Journal of Targeting, Measurement and Analysis for Marketing, 12(3), 256-268.

Cecere, G., Corrocher, N., \& Battaglia, R. D. (2015). Innovation and competition in the smartphone industry: Is there a dominant design? Telecommunications Policy, 39(3-4), 162-175.

Chung, D., \& Chun, S.G. (2011). An exploratory study on determining factors for the smartphone selection decisions. Issues in Information Systems, 12(1), 291-300.

Demireli, C. (2014). Tüketici yenilikçiliği ve gönüllü sade yaşam tarzı arasındaki ilişkinin incelenmesi. Yönetim ve Ekonomi Araştırmaları Dergisi, 12(24), 320-337.

De Ruyter, K., Wetzels, M., \& Bloemer, J. (1998). On the relationship between perceived service quality, service loyalty and switching costs. International Journal of Service Industry Management, 9(5), 436-453.

Dobre, C., Dragomir, A., \& Preda, G. (2009). Consumer innovativeness: A marketing approach. Management \& Marketing, 4(2), 19-34.

Dodds, W. B., Monroe, K. B., \& Grewal, D. (1991). Effects of price, brand, and store information on buyers' product evaluations. Journal of Marketing Research, 28(3), 307-319.

Eryiğit, C., \& Kavak, B. (2011). Tüketici yenilikçiliğinin tutumsal ve davranışsal uyumunun incelenmesi. Hacettepe Üniversitesi iktisadi ve Idari Bilimler Fakültesi Dergisi, 29(2), 95-113.

Fornell, C., \& Larcker, D. F. (1981). Evaluating structural equation models with unobservable variables and measurement error. Journal of Marketing Research, 18(1), 39-50. 
Fornell, C., Johnson, M. D., Anderson, E. W., Cha, J., \& Bryant B. E. (1996). The American Customer Satisfaction Index: Nature, purpose and findings. Journal of Marketing, 60, 7-18.

Gefen, D. (2002). Customer loyalty in e-commerce. Journal of the association for information systems, 3(1), 2.

Gale, B., \& Wood, R. C. (1994). Managing customer value: creating quality and service that customers can see. Simon and Schuster.

Global Mobile Marketing Report (2018). Retrieved February 02, 2018, from, www.newzoo.com

Goldsmith, R. E., \& Hofacker, C. F. (1991). Measuring consumer innovativeness. Journal of The Academy of Marketing Science, 19(3), 209-221.

Hair, J. F., Black, W. C., Babin, B. J., \& Anderson, R. E. (1998). Multivariate data analysis (5th ed.). Upper Saddle River, NJ.: Prentice-Hall.

Hau, L. N., \& Thuy, P. N. (2012). Impact of service personal values on service value and customer loyalty: a cross-service industry study. Service business, 6(2), 137-155.

Heide, J. B., \& Weiss, A. M. (1995). Vendor consideration and switching behavior for buyers in high-technology markets. The Journal of Marketing, 59(3), 30-43.

Hirunyawipada, T., \& Paswan, A. K. (2006). Consumer innovativeness and perceived risk: Implications for high technology product adoption. Journal of Consumer Marketing, 23(4), 182-198.

Hong, J. C., Lin, P. H., \& Hsieh, P. C. (2017). The effect of consumer innovativeness on perceived value and continuance intention to use smartwatch. Journal of Computers in Human Behavior, 67, 264-272.

Hsiao, K. L. (2013). Android smartphone adoption and intention to pay for mobile internet: Perspectives from software, hardware, design, and value. Library Hi Tech, 31(2), 216-235.

Huang, J., \& Zhang, D. (2008). Customer value and brand loyalty: Multi-dimensional empirical test. In Future Information Technology and Management Engineering, FITME'08. International Seminar on. 102-106. IEEE.

Jackson, B. B. (1985). Winning and keeping industrial customers. Lexington Books.

Kambar, R. (2016). Moda ürünlerinde güdülenmiş tüketici yenilikçiliğinin satın alma ilgilenimi üzerindeki etkisi. KOSBED, $32,149-166$.

Karaaslan, İ. A., \& Budak, L. (2012). Üniversite öğrencilerinin cep telefonu özelliklerini kullanımlarının ve gündelik iletişimlerine etkisinin araştırılması. Journal of Yasar University, $7(26), 4549-4571$

Kavak, B., Taner, N., \& Kazancı, Ş. (2016). Yeniliği benimseyen kategorilerinin yenilikçi davranış güdüleri açısından farklııkları: Akıllı telefon kullanıcıları üzerinde bir inceleme. Pazarlama Teorisi ve Uygulamaları Dergisi, 2(2), 91 121.

Kim, Y., Seoh, H., Lee, S., \& Lee, B. G. (2010). Analyzing user's intention and innovation diffusion of smartphones. In Ubiquitous Information Technologies and Applications (CUTE), 2010 Proceedings of the 5th International Conference on (1-6). IEEE.

Kirsi, F. (2011). Smartphone users in creation of customer value: A value centered approach to product carbon foot print. University of Tampere, Master Thesis.

Lee, J., Lee, J., \& Feick, L. (2001). The impact of switching costs on the customer satisfaction-loyalty link: Mobile phone service in France. Journal of Services Marketing, 15(1), 35-48.

Li, G., Zhang, R., \& Wang, C. (2015). The role of product originality, usefulness and motivated consumer innovativeness in new product adoption intentions. Journal of Product Innovation Management, 32(2), 214-223.

Ling, M., \& Yuan, P. (2012). An empirical research: Consumer intention to use smartphone based on consumer innovativeness. In Consumer Electronics, Communications and Networks (CECNet), 2nd International Conference on (2368-2371). IEEE.

Louarn, P. L. (1997). La tendance à innover des consommateurs: Analyse conceptuelle et proposition d'une echelle de mesure. Recherche et Applications en Marketing (French Edition), 12(1), 3-19.

Malhotra, N. K. (2010). Marketing research: An applied orientation (6th edition). New Jersey: Pearson Education.

Midgley, D. F. (1977) Innovation and new product marketing. New York: Halsted Press, John Wiley \& Sons, Inc.,

Midgley, D. F., \& Dowling, G. R. (1978). Innovativeness: The concept and its measurement. Journal of Consumer Research, 4(4), 229-242.

Nakamura, A. (2010). Estimating switching costs Involved in changing mobile phone carriers in Japan: Evaluation of lockin factors related to japan's sim card locks. Telecommunications Policy, 34(11), 736-746. 
Nasution, R. A., \& Garnida, N. (2010). A review of the three streams of consumer innovativeness. In Technology Management for Global Economic Growth (PICMET), Proceedings of PICMET'10, 1-11. IEEE.

Ningsih, M. S., \& Segoro, W. (2014). The influence of customer satisfaction, switching cost and trusts in a brand on customer loyalty-the survey on student as IM3 users in depok, Indonesia. Procedia-Social and Behavioral Sciences, 143, 1015-1019.

Oyeniyi, O., \& Abiodun, A. J. (2010). Switching cost and customers loyalty in the mobile phone market: The Nigerian experience. Business Intelligence Journal, 3(1), 111-121.

Özoğlu, B., \& Bülbül, H. (2013). Güdülenmiş tüketici yenilikçiliği ve algılanan risk ölçeklerinin geçerlilik ve güvenilirlik çalışması. Journal of Alanya Faculty of Business/Alanya Isletme Fakültesi Dergisi, 5(3), 131-139.

Park, Y., \& Koo, Y. (2016). An empirical analysis of switching cost in the smartphone market in South Korea. Telecommunications Policy, 40(4), 307-318.

Peter, J. P. (1981). Construct validity: A review of basic Issues and marketing practices. Journal of Marketing Research, XVIII, 133-145.

Raju, P. S. (1980). Optimum stimulation level: its relationship to personality, demographics, and exploratory behavior. Journal of Consumer Research, 7(3), 272-282.

Roehrich, G. (1994). Innovativités hédoniste et sociale: Proposition d'une echelle de mesure. Recherche et Applications en Marketing (French Edition), 9(2), 19-42.

Roehrich, G. (2004). Consumer innovativeness: concepts and measurements. Journal of Business Research,57(6),671677.

Rogers, E. M. (1995). Diffusion of innovations (3th Edition). The Free Press, New York: McMillan Publishing Company.

Rogers, E. M. (2002). Diffusion of preventive innovations. Addictive Behaviors. 27(6), 989-993.

Saeed, R., Zameer, H., Awan, I., \& Ullah, I. (2014). A study of consumer innovativeness and motivations behind adoption of innovation. International Journal of Academic Research in Business and Social Sciences, 4(7), 340-349.

Samudro, A., Sumarwan, U., Yusuf, E., \& Simanjuntak, M. (2018). Perceived value, social bond, and switching cost as antecedents and predictors of customer loyalty in the B2B chemical industry context: A literature review. International Journal of Marketing Studies, 10(4), 124-138.

Schermelleh-Engel, K., Helfried M., \& Hans, M. (2003). Evaluating the fit of structural equation models: Tests of significance and descriptive goodness-of-fit measures. Methods of Psychological Research Online, 8(2), 23-74.

Sekaran, U. (2000). Research methods for business: A skill-building approach. UK: Wiley\&Sons.

Shy, O. (2002). A quick-and-easy method for estimating switching costs. International Journal of Industrial Organization, 20(1), 71-87.

Steenkamp, J. B. E., Hofstede, F. T., \& Wedel, M. (1999). A cross-national investigation into the individual and national cultural antecedents of consumer innovativeness. The Journal of Marketing, 63(2), 55-69.

Sun, H. (2009). The impact of customer value and internet shopping mall on customer loyalty and customer satisfaction. In ICE-B, 279-286.

Şahin, Ş. (2017). Şikayete yönelik tutum, değiştirme maliyeti, tüketici güveni, müşteri memnuniyeti ve müşteri sadakati ilişkisi: bankacılık sektörü üzerine bir uygulama. Balıkesir Üniversitesi Sosyal Bilimler Enstitüsü, Yüksek Lisans Tezi, Balıkesir.

Şenbabaoglu, E. (2017). The impact of the service innovativeness on perceived overall service quality, customer loyalty and perceived customer value in shopping sites. Marketing and Branding Research, 4(4), 371.

Tussyadiah, I. P. (2016). The influence of innovativeness on on-site smartphone use among american travelers: Implications for context-based push marketing. Journal of Travel \& Tourism Marketing, 33(6), 806-823.

Vandecasteele, B., \& Geuens, M. (2010). Motivated consumer innovativeness: Concept, measurement, and validation. International Journal of Research in Marketing, 27(4), 308-318.

Venkatraman, M. P., \& Price, L. L. (1990). Differentiating between cognitive and sensory innovativeness: Concepts, measurement, and implications. Journal of Business Research, 20(4), 293-315.

Wang, C. Y. (2010). Service quality, perceived value, corporate ımage, and customer loyalty in the context of varying levels of switching costs. Psychology \& Marketing, 27(3), 252-262.

Yang, Z., \& Peterson, R. T. (2004). Customer perceived value, satisfaction, and loyalty: The role of switching costs. Psychology \& Marketing, 21(10), 799-822. 

Telefon Pazarı Örneği

Yıldız, E., \& Koç, M. E. (2017). Marka mirası ve marka güveninin satın alma niyeti, müşteri tatmini ve marka sadakati üzerindeki etkileri. Dumlupınar Üniversitesi Sosyal Bilimler Dergisi, 86-104.

Yoo, J., Yoon, Y., \& Choi, M. (2010). Importance of positive reputation for smartphone adoption. In Information and Communication Technology Convergence (ICTC), International Conference on (314-318). IEEE.

Zeithaml, V. A. (1988). Consumer perceptions of price, quality, and value: A means-end model and synthesis of evidence. The Journal of Marketing, 52(3), 2-22. 